\title{
About the Dark and Bright Sides of Self-efficacy: Workaholism and Work Engagement
}

\author{
Mario Del Líbano ${ }^{1}$, Susana Llorens ${ }^{1}$, Marisa Salanova ${ }^{1}$, and Wilmar B. Schaufeli ${ }^{2}$ \\ ${ }^{1}$ Universitat Jaume I (Spain) \\ ${ }^{2}$ Utrecht University (The Netherlands)
}

\begin{abstract}
Taking the Resources-Experiences-Demands Model (RED Model) by Salanova and colleagues as our starting point, we tested how work self-efficacy relates positively to negative (i.e., work overload and work-family conflict) and positive outcomes (i.e., job satisfaction and organizational commitment), through the mediating role of workaholism (health impairment process) and work engagement (motivational process). In a sample of 386 administrative staff from a Spanish University (65\% women), Structural Equation Modeling provided full evidence for the research model. In addition, Multivariate Analyses of Variance showed that self-efficacy was only related positively to one of the two dimensions of workaholism, namely, working excessively. Finally, we discuss the theoretical and practical contributions in terms of the RED Model.
\end{abstract}

Keywords: self-efficacy, workaholism, work engagement.

Tomando como base teórica el Modelo de Recursos-Experiencias-Demandas (Modelo RED) de Salanova y colegas, analizamos cómo la autoeficacia laboral se relaciona positivamente con resultados negativos (i.e., sobrecarga cuantitativa y conflicto trabajo-familia) y con resultados positivos (i.e., satisfacción laboral y compromiso organizacional), a través del rol mediador de la adicción al trabajo (proceso de erosión) y el engagement o vinculación laboral (proceso motivacional). En una muestra de 386 trabajadores PAS (Personal de Administración y Servicios) de una Universidad Española (65\% mujeres), utilizando Ecuaciones Estructurales obtuvimos evidencia total para el modelo de investigación propuesto. Además, diversos Análisis Multivariados de Varianza mostraron que la autoeficacia se relacionaba positivamente solo con una de las dos dimensiones de la adicción al trabajo, esto es, trabajar excesivamente. Finalmente, discutimos las contribuciones teóricas y prácticas del estudio basándonos en el Modelo RED.

Palabras clave: autoeficacia, adicción al trabajo, vinculación laboral.

This study was supported by grants from the Spanish Ministerio de Ciencia e Innovación (\#PSI2008-01376/PSIC), the Spanish Ministerio de Trabajo y Asuntos Sociales (\#411/UJI/SALUD), and Universitat Jaume I \& Bancaixa (\#P11B2008-06).

Correspondence concerning this paper should be addressed to Mario Del Líbano Miralles. Department of Social Psychology. Universitat Jaume I. Avenida Sos Baynat, s/n. 12071 Castellón (Spain). Tel. +34-964729571. Fax. +34-964729262. E-mail: libano@uji.es 
Globalization of markets, demands from the environment, and the economic crisis are all indicators that society is in a state of continuous change. Those who are able to adapt to the changes taking place have more opportunities to improve their skills and perceive these changes as challenges. The extent to which people believe in their own capabilities is a crucial aspect in order to achieve this adaptation, especially in organizations which are continuously optimizing their procedures to obtain maximum profits. In this context, employees need to have confidence in themselves in order to perform and feel well. This confidence in one's capabilities has been called self-efficacy and, according to Social Cognitive Theory (SCT), it is defined as the "beliefs in one's capabilities to organize and execute the courses of action required to produce given attainments" (Bandura, 1997, p. 3). Self-efficacious people are those who believe that they have the power to produce the desired effects by their own actions, to be motivated to act, to persevere in the face of difficulties, and to be resilient in the face of adversity.

A growing body of research attests the impact of selfefficacy on positive consequences such as performance (Stajkovic, Lee, \& Nyberg, 2009), affect (Salanova, Llorens, \& Schaufeli, 2011) and work engagement (Llorens, Schaufeli, Bakker, \& Salanova, 2007; Salanova, Llorens et al., 2011; Salanova, Lorente, Chambel, \& Martínez, 2011). However, although past research has confirmed the existence of links between self-efficacy and positive consequences, other scholars are focusing on the impact of self-efficacy on negative consequences. For example, Vancouver, Thompson, Tischner and Putka (2002) conducted two studies which show that by manipulating self-efficacy in an analytic game, it negatively relates to performance in the next trial. Specifically, a manipulation designed to increase self-efficacy increased self-efficacy but had no overall relation to performance at the between-person level. However, at the within-person level, the manipulation not only increased self-efficacy but also decreased performance in the next game. The explanation is that self-efficacy leads to overconfidence and, hence, increases the likelihood of committing cognitive errors during the game. In a similar vein, Vancouver and Kendall (2006) take control theory as their basis to claim that when self-efficacy is relatively high it is likely to play a negative role on resource allocation, which may adversely affect performance. Specifically, selfefficacy negatively related to motivation and exams performance at the intra-person level of analysis despite a significant positive relationship with performance at the between-persons level. The authors explained that when self-efficacy is relatively high, we may expect individuals to use fewer resources (e.g., spending less time studying) because their discrepancy between the desired level of preparedness and the perception of preparedness, is smaller compared to when their self-efficacy is lower.

More research is required to investigate the simultaneous relationships between self-efficacy and its potential positive as well as negative consequences. The current study is innovative because we show how work self-efficacy positively relates to an intrinsically positive construct such as work engagement, but also to an intrinsically negative concept like workaholism. Work engagement is defined as "a positive, fulfilling, work-related state of mind that is characterized by vigor, dedication, and absorption in the activity" (Salanova, Schaufeli, Llorens, Peiró, \& Grau, 2000, p. 119; Schaufeli, Salanova, González-Romá, \& Bakker, 2002), while workaholism is defined as "the tendency to work excessively hard in a compulsive way" (Schaufeli, Taris, \& Bakker, 2008, p. 204). Moreover, for the very first time, we investigate how work self-efficacy relates to positive (i.e., job satisfaction and organizational commitment) and negative outcomes (i.e., work overload and work-family conflict) through the mediating role of work engagement and workaholism, respectively. Another innovation of this study is that it proposes an extension of the ResourcesExperiences-Demands (RED) Model (it will be explained below, p. 5) (Salanova, Cifre, Martínez, \& Llorens, 2007; Salanova, Cifre, Martínez, Llorens, \& Lorente, 2011), since we specify the relationship among work self-efficacy, work engagement, workaholism, and positive as well as negative outcomes. More particularly, we include two proximal consequences of self-efficacy (i.e., work engagement and workaholism) as well as four distal outcomes (i.e., work overload, work-family conflict, job satisfaction, and organizational commitment). In addition, again for the first time, we test the relationship among self-efficacy and two different psychological constructs (Schaufeli, Taris, \& Bakker, 2006; Schaufeli, Taris, \& Van Rhenen, 2008), namely work engagement and workaholism, which are analyzed simultaneously.

To sum up, the objective of this study is to analyze the role played by work self-efficacy in these two different phenomena (i.e., work engagement and workaholism) and positive (i.e., job satisfaction and organizational commitment) as well as negative outcomes (i.e., work overload and workfamily conflict), respectively, under the assumptions of the RED Model (Salanova et al., 2007; Salanova, Cifre et al., 2011).

\section{Explaining self-efficacy, workaholism and work engagement: the RED Model}

The RED Model (Salanova et al., 2007; Salanova, Cifre et al., 2011) constitutes an extension of previous models, such as the Job Demands-Control Model (JDC; Karasek, 1979) and the Job Demands-Resources Model (JDR) (Demerouti, Bakker, Nachreiner, \& Schaufeli, 2001; Schaufeli \& Bakker, 2004). The distinctive element of the RED Model is that it considers that the psychological health of employees depends not only on job demands (e.g., role conflict) and job resources (e.g., social support), but also on personal resources. In fact, the RED Model considers 
personal resources in general, and (work) self-efficacy in particular, as the cornerstone in the perception of job demands and job resources: employees interpret their social and work environment (i.e., job demands and job resources) in terms of their levels of work self-efficacy (Salanova, Lorente, \& Vera, 2009).

In accordance with the RED and the JD-R Models, job demands are those physical, psychological, social, or organizational aspects of work that require a physical and/or psychological effort (cognitive or emotional) and are therefore associated with certain physiological and/or psychological costs. Inversely, job resources refer to those physical, social, or organizational aspects of the job that may: (1) reduce job demands and the associated physiological and psychological costs, (2) be functional for achieving work goals, or (3) stimulate personal growth, learning, and development. Finally, personal resources are defined as such aspects of the self that are generally linked to resiliency and refer to individuals' sense of their ability to control and impact upon their environment successfully (Hobfoll, Johnson, Ennis, \& Jackson, 2003).

Based on the assumptions of the RED Model, the combination of job demands as well as job and personal resources (i.e., self-efficacy) evokes two relatively independent psychological processes (i.e., health impairment and motivation). According to the health impairment process, when employees have low levels of self-efficacy, they believe that they do not control the work environment in an effective way. This situation requires a sustained effort and consequently may exhaust employees' resources and lead to energy depletion and subsequent health problems (see Caplan, Cobb, French, Harrison, \& Pinneau, 1975). For example, different scholars have argued that, in accordance with the health impairment process, employees in various occupational groups with low levels of selfefficacy perceive more specific job demands in the work context (e.g., work overload or emotional demands), which in turn predict exhaustion (i.e., severe fatigue) among various occupational groups (e.g., Bakker, Demerouti, \& Euwema, 2005; Bakker, Demerouti, \& Schaufeli, 2003).

In contrast, in accordance with the motivational process, the availability of self-efficacy acts as a motivational mechanism which leads to the perception of more job resources. When self-efficacy is high, employees believe that they are controlling their environment in a correct way and they are more likely to experience fewer demands and more resources. Thus, the higher work self-efficacy is, the more likely it is that job demands will be seen as challenges (and not as hindrances or stressors) and the more favorable the perception of the job will be. The (intrinsic and extrinsic) motivational potential of job resources pushes employees to meet their goals and to experience positive outcomes such as work engagement, which is exemplified by high effort, persistence, dedication and absorption at work (Llorens, Bakker, Schaufeli, \& Salanova, 2006; Salanova, Schaufeli,
Xanthopoulou, \& Bakker, 2010) and more opportunities to recovery (Eden, 2001; Sonnentag \& Kruel, 2006). It also encourages them to be committed to their job because they derive fulfillment from it (Hackman \& Oldham, 1980).

In conclusion, self-efficacy appears in the RED Model as a key element predicting employees' psychological health (e.g., workaholism and work engagement) as well as positive and negative outcomes, and it plays a crucial role in both parallel processes: the health impairment and the motivational processes.

\section{The health impairment process of self-efficacy and workaholism}

In accordance with the RED Model, work self-efficacy relates to workaholism by the health impairment process. Although various definitions of workaholism have been proposed since the term was coined by Oates (1971), we agree with those who proposed that workaholism can be considered as being negative in nature (Schaufeli, Taris et al., 2006). Also Kanai (2009) refers to it as an undesirable consequence, and Killinger (1992) states that it is a complex negative process that eventually affects the person's ability to function properly. We adopt the definition of Schaufeli, Taris, and Bakker (2008) that describes workaholism as "the tendency to work excessively hard in a compulsive way" (p. 204). More specifically, workaholism is composed of two dimensions, namely: working excessively and working compulsively. On the one hand, working excessively (the behavioral component) points to the fact that workaholics tend to allocate an exceptionally large amount of time to work and that they work beyond what is reasonably expected of them in order to meet organizational or economic requirements. On the other hand, working compulsively (the cognitive component) refers to the fact that workaholics are obsessed with their work and persistently and frequently think about work, even when they are not working. This definition agrees with the most recent analysis of scholarly definitions that concludes that working hard at the expense of other important life roles and a strong internal drive to work are two key aspects of workaholism (Ng, Sorensen, \& Feldman, 2007). Thus, workaholism can be understood as the result of the combination of both a behavioral and cognitive components.

Even though the literature shows that self-efficacy generates well-being through appropriate responses to the demands (e.g., Salanova, Grau, Llorens, \& Schaufeli, 2001), the relationship between work self-efficacy and workaholism seems to be positive, and high levels of self-efficacy could be related to high levels of workaholism ( $\mathrm{Ng}$ et al., 2007). Only one study has been conducted to investigate the influence of self-efficacy on workaholism. Burke, Matthiesen, and Pallesen (2006) examined the effects of self-efficacy (i.e., a generalized measure of self-efficacy) on workaholism which was measured by work involvement, 
feeling a drive to work because of internal pressures and work enjoyment, as proposed by Spence and Robins (1992). Results showed that self-efficacy related positively and significantly to workaholism, i.e., the more self-efficacious the employee is, the more workaholic, and vice versa.

Given the scarcity of studies conducted on the relationship between self-efficacy and workaholism, more specific studies are needed to determine the process behind the development of workaholism. According to Bandura (2001), rather than general, specific measures of self-efficacy should be used because these show more consistent and robust relationships with psychosocial health variables (Grau, Salanova, \& Peiró, 2000; Pajares \& Miller, 1995; Salanova, Peiró, \& Schaufeli, 2002). In this context, Parker (2000) showed that breadth self-efficacy is perhaps a more useful measure than specific task-based self-efficacy. Seemingly, a meta-analysis of self-efficacy and work performance (i.e., Judge, Jackson, Shaw, Scott, \& Rich, 2007) also suggested that task-specific efficacy may not be the optimal way to conceptualize the concept depending on the characteristics of the sample. Hence, in the present study we tested the relationship between specific (no task-based) self-efficacy (i.e., work self-efficacy) and workaholism. Furthermore, and following the health impairment process proposed by the RED Model, the relationship between workaholism and two relevant negative outcomes, i.e. work overload and workfamily conflict, was also tested. Research (e.g., Kanai \& Wakabayashi, 2001; Kanai, Wakabayashi, \& Fling, 1996; Snir \& Harpaz, 2004) has shown that workaholics perceive these two job demands as negative consequences of their excessive and compulsive work, and thereby they are considered as outcomes in our study.

Hence, in accordance with previous research and our theoretical model (see Figure 1) we expect to find that:

Hypothesis 1. Work self-efficacy relates positively to workaholism, which in turn relates positively to work overload and work-family conflict through the health impairment process.

\section{The motivational process of self-efficacy and work engagement}

According to the second proposition of the RED Model, self-efficacy could regulate work engagement by means of a motivational process. Despite the existence of different meanings of the concept of work engagement (Macey \& Schneider, 2008), the most widely accepted definition is the one which considers work engagement as "a positive, fulfilling, work-related state of mind that is characterized by vigor, dedication, and absorption in the activity" (Salanova et al., 2000, p. 119; Schaufeli, et al., 2002). Vigor is characterized by willingness to invest effort in one's work, persistence in the face of difficulties, and high levels of energy and mental resilience while working. Dedication refers to a particularly strong work involvement and identification with one's job. And finally, absorption denotes being fully concentrated and engrossed in one's work, whereby time passes quickly and one has difficulties detaching oneself from work (see also Salanova \& Schaufeli, 2009).

Engaged employees have a sense of energetic and effective connection with their work activities and they see themselves as able to deal well with the demands of their job. Unlike workaholics, they enjoy doing things outside work, they do not feel guilty when they are not working, and they do not work hard because of a strong and irresistible inner drive, but because work is fun for them (Schaufeli, Taris et al., 2006). Thus it seems that the correlates of workaholism and work engagement are different. Engaged employees usually have good social relationships, they do not have any problems with their family derived from the long hours they spend working, and they do not have any physical or mental health problems derived from their job (Salanova \& Schaufeli, 2009; Schaufeli, Taris, \& Van Rhenen, 2008).

There are many studies that link self-efficacy with positive outcomes and consequences. For instance, Latham (2005) found positive relationships among self-efficacy, motivation, commitment and job performance, and Judge and Bono (2001) documented the positive intercorrelation of self-efficacy on levels of job satisfaction. Positive relationships also have been found between academic self-efficacy and academic performance (Ellias \& MacDonald, 2007). And in another study, Salanova, Llorens et al. (2011) revealed that efficacy beliefs were associated with positive emotions (especially enthusiasm) and work engagement. Thus, due to high levels of self-efficacy, the levels of work engagement in the workplace can be increased in the long term via positive affect (i.e., enthusiasm, comfort and enthusiasm) in gain cycles and spirals of efficacy beliefs, affect and engagement.

The relationship between self-efficacy and work engagement has received more attention (e.g., Schaufeli \& Salanova, 2007a) than the relationship between self-efficacy and workaholism. Different scholars have revealed that selfefficacy and work engagement are positively related (Llorens et al., 2007; Salanova, Llorens, Cifre, Martínez, \& Schaufeli, 2003; Xanthopoulou, Bakker, Demerouti, \& Schaufeli, 2007). For instance, in a longitudinal study, Llorens et al. (2007) found that the higher self-efficacy was, the higher work engagement was three weeks later. Furthermore, in a sample of highly skilled Dutch technicians, Xanthopoulou et al. (2007) found evidence that engaged employees are highly selfefficacious. Results showed that they believe they are able to meet the demands they face in a broad array of contexts. These findings were replicated and expanded in a 2-year follow-up study (Xanthopoulou, Bakker, Heuven, Demerouti, $\&$ Schaufeli, 2008). For a review of recent research on selfefficacy and work engagement, see Salanova et al. (2010).

Despite the evidence for the positive relationship between self-efficacy and work engagement, further research is necessary to confirm the results obtained in these previous 
studies and to understand the process of work engagement by using the RED Model. In order to gain a better understanding of this process, in the present study we tested the relationship between work self-efficacy and work engagement. Furthermore, and following the motivational process proposed by the $R E D$ Model, we also tested the relationship between work engagement and two relevant positive outcomes, i.e. job satisfaction and organizational commitment.

Thus, in accordance with previous research and our theoretical model (see Figure 1) we expect to find that:

Hypothesis 2. Work self-efficacy relates positively to work engagement (i.e., vigor, dedication and absorption), which in turn relates positively to job satisfaction and organizational commitment through a motivational process.

\section{Method}

\section{Participants and procedure}

The sample consisted of 386 administrative staff from a Spanish University. Employees had work experience ranging from 1 to 45 years and the mean number of years worked was $14(S D=7.2)$. They answered an on-line questionnaire drawn up in order to implement an evaluation of psychosocial risks. Firstly, we met with the stakeholders of employees in order to explain the phases of the evaluation (e.g., objectives, procedure, diagnosis, etc.). Secondly, we generated several user-identifications and passwords that were confidentially and anonymously distributed among employees. Finally, we informed the stakeholders of the results by means of a professional report and they explained the main conclusions to the rest of the employees.

\section{Measures}

Work self-efficacy. We measured work self-efficacy using four items from RED.es (Salanova et al., 2007), which reflect specific staff beliefs in their future capacities to produce accurate levels of performance. An example of the items is: 'I can do my job well although I have to solve difficult problems'. Workers were asked to indicate the extent to which they agreed with each sentence on a seven-point rating scale ranging from 0 ('never') to 6 ('always/everyday').

Workaholism. We measured workaholism by the short Spanish version (10 items) (Del Líbano, Llorens, Salanova, \& Schaufeli, 2010) of the DUWAS (DUtch Work Addiction Scale; Schaufeli, Shimazu, \& Taris, 2009), which includes two dimensions: working excessively (five items; e.g., ' $I$ stay busy and keep my irons in the fire') and working compulsively (five items; e.g., 'I often feel that there's something inside me that drives me to work hard'). Scores ranged from 1 ('almost never') to 4 ('almost always').

Work engagement. We measured work engagement using the short Spanish version (nine items) of the UWES (Utrecht

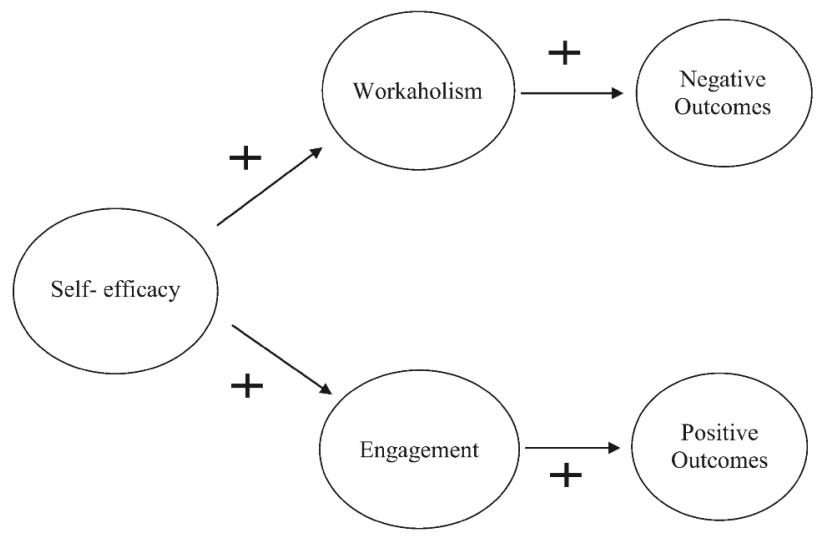

Figure 1. Research model

Work Engagement Scale; Schaufeli, Bakker, \& Salanova, 2006), which includes three dimensions: vigor (three items; e.g., 'At my work, I feel bursting with energy'), dedication (three items; e.g., 'I am enthusiastic about my job') and absorption (three items; e.g., 'I feel happy when I am working intensely'). Scores ranged from 0 ('never') to 6 ('always').

Negative outcomes. We measured negative outcomes by two dimensions: work overload and work-family conflict. We assessed work overload using an adapted version of the Beehr, Walsh, and Taber (1976) scale composed of four items. An example of the items is 'I have more work that I can do'. Work-family conflict was measured using the RED.es scale by Salanova et al. (2007) composed of four items. An example of the items is 'I am so worried about work matters that I forget my personal affairs'. Scores ranged from 0 ('never') to 6 ('always').

Positive outcomes. We measured positive outcomes by job satisfaction and organizational commitment. Job satisfaction was measured by four items from the RED.es questionnaire (Salanova et al., 2007) referring to satisfaction with job, colleagues, and supervisor. To answer the items a seven-face scale was used (Kunin, 1955), an affect-based measure. An example of the items used is: 'What is your level of satisfaction with the work you do in your job?' Organizational commitment was measured by three items from RED.es (Salanova et al., 2007). An example of the items is: "The problems I have in my company are "my", problems'. Scores ranged from 0 ('never') to 6 ('always').

\section{Data analyses}

Firstly, we computed the internal consistencies (Cronbach's $\alpha$ ), descriptive analyses, and intercorrelations among the variables with the PASW 18.0 program. Secondly, we computed Harman's single factor test with Confirmatory Factor Analyses (CFA) (e.g. Iverson \& Maguire, 2000; cf. Podsakoff, MacKenzie, Lee, \& Podsakoff, 2003) using the 
Table 1

Means (M), Standard Deviations (SD), Internal Consistencies (Cronbach's $\alpha$ on the diagonal) and zero-order correlations in the sample $(N=386)$

\begin{tabular}{lcccccccccccc}
\hline Dimension & \multicolumn{1}{c}{ University Staff } & \multicolumn{4}{c}{ Correlations } \\
& $M$ & $S D$ & $(1)$ & $(2)$ & $(3)$ & $(4)$ & $(5)$ & $(6)$ & $(7)$ & $(8)$ & $(9)$ & $(10)$ \\
\hline 1. Self-efficacy & 4.48 & .91 & .94 & $.20^{* *}$ & .04 & $.41^{* *}$ & $.22^{* *}$ & $.32^{* *}$ & .08 & .08 & $.15^{* *}$ & $.12^{*}$ \\
2. Working Excessively & 2.28 & .62 & - & .73 & .49 & $.14^{* *}$ & $.19^{* *}$ & $.21^{* *}$ & $.65^{* *}$ & $.61^{* *}$ & $.15^{* *}$ & .08 \\
3. Working Compulsively & 3.6 & 1.8 & - & - & .74 & .07 & $-.10^{*}$ & $.14^{* *}$ & $.35^{* *}$ & $.42^{* *}$ & $-.22^{* *}$ & .62 \\
4. Vigor & 4.63 & .87 & - & - & - & .84 & $.59^{* *}$ & $.51^{* *}$ & .07 & .07 & $.49^{* *}$ & $.33^{* *}$ \\
5. Dedication & 3.74 & 1.24 & - & - & - & - & .92 & $.51^{* *}$ & $.11^{*}$ & .08 & $.57^{* *}$ & $.35^{* *}$ \\
6. Absorption & 3.66 & 1.02 & - & - & - & - & - & .79 & .09 & $.18^{* *}$ & $.28^{* *}$ & $.27^{* *}$ \\
7. Work Overload & 3.3 & 1.15 & - & - & - & - & - & - & .90 & $.48^{* *}$ & $-.16^{* *}$ & -.05 \\
8. Work-Family conflict & 2.16 & 1.45 & - & - & - & - & - & - & - & .72 & $-.21^{* *}$ & -.04 \\
9. Job satisfaction & 3.74 & 1.04 & - & - & - & - & - & - & - & - & .66 & $.43^{* *}$ \\
10. Org. Commitment & 3.64 & 1.08 & - & - & - & - & - & - & - & - & - & .76 \\
\hline
\end{tabular}

Notes. $* p<.05, * * p<.01$

AMOS (Analysis of MOment Structures) software package (v. 18.0) for the study variables in order to test for bias due to common method variance. Thirdly, the AMOS was employed to implement Structural Equation Modeling (SEM) methods by using Maximum Likelihood Estimation methods to establish the relationships between the model variables (Byrne, 2001). We used seven variables (i.e., self-efficacy, workaholism, work overload, work-family conflict, work engagement, job satisfaction and organizational commitment) as latent variables in our model. Each latent variable was composed of two or more observed variables.

We tested the fit of the research model to the data by means of the chi-square difference test (Jöreskog \& Sörbom, 1986). In addition to the chi-square statistic, the analyses also assessed the Goodness-of-Fit Index (GFI), the Root Mean Square Error of Approximation (RMSEA) and the Tucker-Lewis Index (TLI). Furthermore, AMOS provides several fit indices that reflect the discrepancy between the hypothesized model and the baseline Null model. We also included the Comparative Fit Index (CFI) (Browne \& Cudeck, 1993). Marsh, Balla, and Hau (1996) recommended the latter because it is less dependent on sample size than the chi-square statistics and the GFI. Since the distribution of the GFI is unknown, there is no statistical test or critical value available (Jöreskog \& Sörbom, 1986). In general, models with fit indices greater than .90 and an RMSEA smaller than .08 indicate a good fit (Hoyle, 1995).

\section{Results}

\section{Descriptive statistics}

Table 1 displays the results of the descriptive analyses; that is, means, standard deviations, internal consistencies $(\alpha)$ and intercorrelations of the scales. All alphas meet the
.70 criterion (Nunnally \& Bernstein, 1994), except job satisfaction, which nevertheless approaches that criterion with a value of .66. As expected, the pattern of correlations shows that variables correlate significantly with each other in $75 \%$ of the cases, that is to say, work self-efficacy is positively and significantly related to workaholism (i.e., working excessively), to work engagement (i.e., vigor, dedication and absorption), and to job satisfaction and organizational commitment, and it is negatively related to work overload and to work-family conflict. Only one unexpected result is obtained, that is, the non-significant relationship between work self-efficacy and one of the dimensions of workaholism, i.e. working compulsively. Furthermore, the results of Harman's single factor test with CFA (e.g., Iverson \& Maguire 2000; cf. Podsakoff et al., 2003) reveal a significantly lower fit to the data, $\chi^{2}(35)=$ 2047.55, RMSEA $=.23, \mathrm{CFI}=.34, \mathrm{IFI}=.35, \mathrm{TLI}=.23$, $\mathrm{AIC}=2107.55$. In order to avoid the problems related to the use of Harman's single factor test (see Podsakoff et al., 2003), we compared the results of the one latent factor, M1, with multiple latent factors, M2, (i.e., work self-efficacy, workaholism, work engagement, work overload, work-family conflict, job satisfaction, and commitment). The results show significantly lower fit of the model with one single factor when compared to the model with multiple latent factors, Delta $\chi^{2}(10)=1780.23, p<.001$. Hence, one single factor could not account for the variance in the data. Consequently, it seems that common method variance is not likely to have occurred in our dataset.

\section{Model fit: Testing the hypotheses}

In order to test our hypotheses, the hypothesized model was tested using SEM. First, we tested the proposed model, Model 1; M1, which assumed that, on the one hand, work self-efficacy relates positively to workaholism, which in 
Table 2

Fit indices of two Structural Equation models $(N=386)$

\begin{tabular}{|c|c|c|c|c|c|c|c|c|c|c|c|c|}
\hline Model & $\chi^{2}$ & $d f$ & GFI & RMSEA & TLI & CFI & $\chi^{2}$ diff & $\Delta d f$ & $\Delta \mathrm{GFI}$ & $\triangle$ RMSEA & $\Delta \mathrm{TLI}$ & $\Delta \mathrm{CFI}$ \\
\hline 1. M1. Hypothetical model & 342.08 & 83 & .90 & .09 & .89 & .91 & & & & & & \\
\hline 2. M2. Final model & 301.82 & 82 & .91 & .08 & .91 & .93 & & & & & & \\
\hline Difference between M2 \& M1 & & & & & & & $40.26 * * *$ & 1 & .01 & .01 & .02 & .02 \\
\hline
\end{tabular}

Notes. $\chi^{2}=$ Chi-square; $d f=$ degrees of freedom; GFI = Goodness-of-Fit Index; RMSEA = Root Mean Square Error of Approximation; $\mathrm{TLI}=$ Tucker-Lewis Index; CFI $=$ Comparative Fit Index.

turn relates positively to work overload and work-family conflict (the health impairment process). On the other hand, work self-efficacy relates positively to work engagement, which in turn relates positively to job satisfaction and organizational commitment (the motivational process). Second, based on the Modification Indexes, we significantly improved, Delta $\chi^{2}(1)=40.26, p<.001$, the hypothesized model, Model 2; M2, by assuming an extra direct relationship between workaholism and job satisfaction. Thus workaholism is negatively related to the employees' perception of the workplace in terms of satisfaction.

Table 2 displays the overall fit indices of the models. The results show that M2 fits the data better than M1, Delta $\chi^{2}(1)=40.26, p<.001$. The SEM show a best model, M2, in which work self-efficacy relates positively to both workaholism and work engagement via the health impairment and the motivational processes. All indicators of the variables included have loadings on the intended latent factors ranging from .14 to .97. Specifically, high work self-efficacy relates positively to workaholism, $\beta=$ $.21, p<.001$, which in turn relates positively to negative outcomes, i.e., work overload, $\beta=.75, p<.001$, and workfamily conflict, $\beta=.74, p<.001$, following the health impairment process. Furthermore, work self-efficacy also relates positively to work engagement, $\beta=.40, p<.001$, which in turn relates positively to positive outcomes, i.e., job satisfaction, $\beta=.86, p<.001$, and organizational commitment, $\beta=.48, p<.001$, through the motivational process. As previous research has shown (e.g., Schaufeli, Taris, \& Van Rhenen, 2008), the double loading of

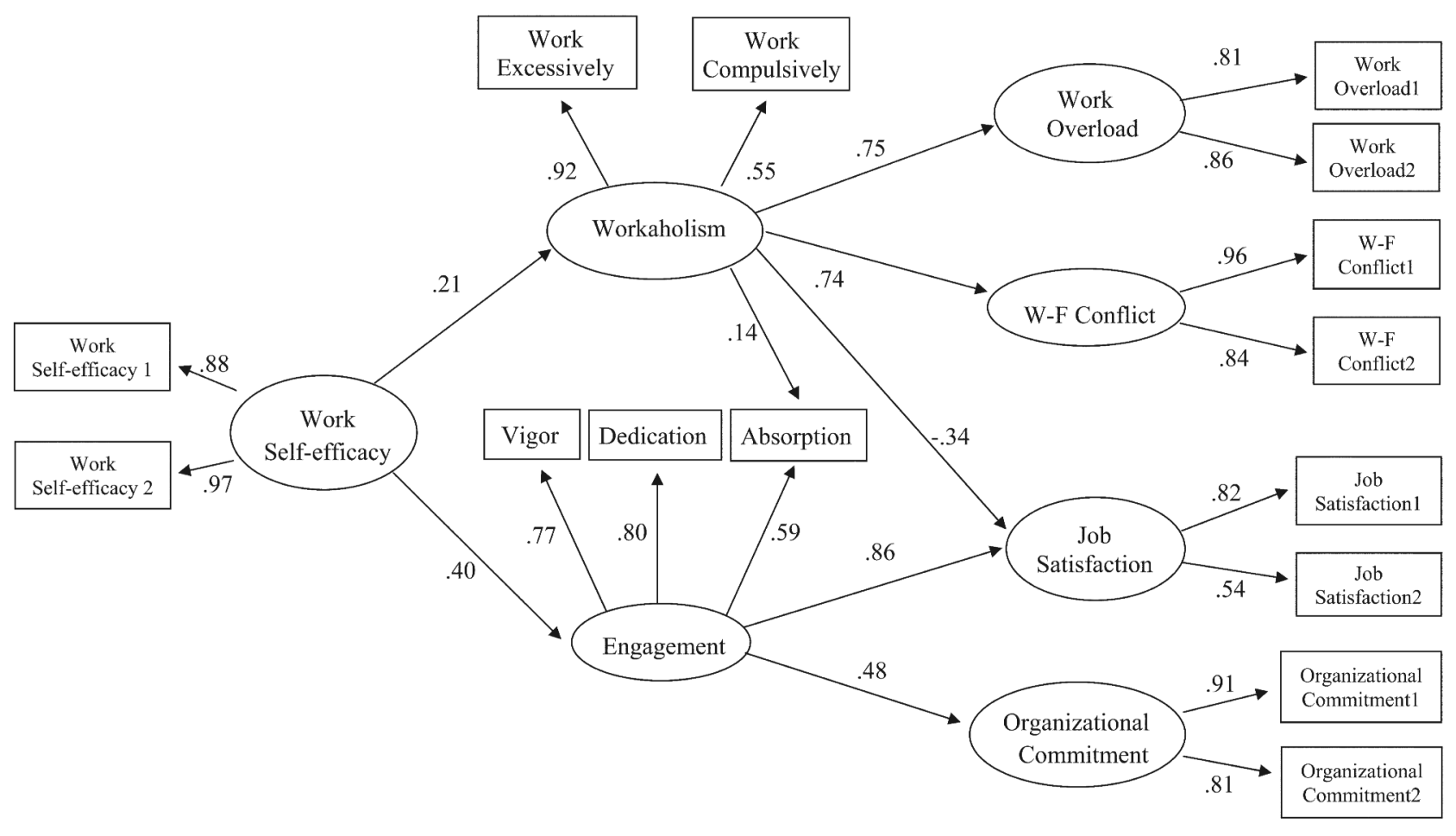

Figure 2. Structural Equation Model $2(\mathrm{~N}=386)$. Note. All the values are significant at .001 
absorption on workaholism, $\beta=.14, p<.001$, and work engagement, $\beta=.59, p<.001$, is also assumed. Moreover, a negative relationship between workaholism and job satisfaction was also obtained, $\beta=-.34, p<.001$.

It is interesting to note that, although the effect of work self-efficacy on workaholism and work engagement is significant in both cases, the impact of work self-efficacy on work engagement is higher, $R^{2}=14 \%$, than on workaholism, $R^{2}=4 \%$. The analysis of the explained variance also reveals workaholism accounts for $55 \%$ of work overload and $56 \%$ of work-family conflict variances, while work engagement accounts for $23 \%$ of organizational commitment and $53 \%$ of job satisfaction (workaholism accounts for $27 \%$ of job satisfaction) variances. The final model with only the significant paths is depicted in Figure 2.

\section{Further analyses}

Finally, in order to conduct an in-depth study of the relationship between self-efficacy and the dimensions of workaholism and work engagement, MANOVAs were performed, using work self-efficacy as the independent variable and vigor, dedication, absorption, working excessively and working compulsively as the dependent variables (see Table 3). Two groups of self-efficacious employees were created, the first consisting of employees with levels of self-efficacy above the mean and the second including those with self-efficacy levels below the mean. Analyses show significant multivariate effects in vigor, $F(1$, $385)=36.11, p<.001$, dedication, $F(1,385)=12.05, p<$ .001 , and absorption, $F(1,385)=20.69, p<.001$. Employees with above-average levels of self-efficacy score higher in these three dimensions than employees who score below average. There are also significant multivariate effects in the working excessively dimension, $F(1,385)=8.77, p$ $<.05$. Employees with above-average levels of self-efficacy score higher in this dimension than employees who score below average. A non-significant multivariate effect is found with the working compulsively dimension, $F(1,385)=1.92$, $p=.17$.

Table 3

Multivariate analysis of variance (MANOVA) with selfefficacy as the independent variable $(N=386)$

\begin{tabular}{lcccc}
\hline Variable & $d f$ & $F$ & $P$ & $\mathrm{n}^{2}$ \\
\hline 1. Vigor & 1,385 & 36.11 & .000 & .086 \\
2. Dedication & 1,385 & 12.05 & .001 & .030 \\
3. Absorption & 1,385 & 20.69 & .000 & .051 \\
4. Working Excessively & 1,385 & 8.77 & .003 & .022 \\
5. Working Compulsively & 1,385 & 1.92 & .167 & .005 \\
\hline
\end{tabular}

Notes. $d f=$ degrees of freedom, $F=$ Effect size, $p=$ probability, $\mathrm{n}^{2}=$ Eta

\section{Discussion}

In this study, we tested a structural model of work selfefficacy, workaholism, and work engagement, as well as negative and positive outcomes in a sample of administrative staff from a Spanish University following the expectations from the RED Model. Specifically, the aim of this study was to analyze the role played by work self-efficacy as a possible antecedent of two different psychological constructs: workaholism (an intrinsically negative construct) and work engagement (an intrinsically positive construct), and some of its positive (i.e., job satisfaction and organizational commitment) and negative (i.e., work overload and work-family conflict) outcomes under the assumptions of the RED Model (Salanova, Cifre et al., 2011). Generally speaking, the results of the present study contribute to our understanding of the key role of work self-efficacy in workaholism and work engagement and its outcomes, following the health impairment and the motivational processes of the RED Model.

Our findings obtained by SEM show that work selfefficacy relates positively to workaholism, which in turn relates positively to negative outcomes (i.e., work overload and work-family conflict) through the health impairment process. Consequently, our results confirm Hypothesis 1. More specifically, work self-efficacy relates positively and significantly to workaholism, which is characterized by high levels of working excessively and working compulsively. Interestingly and as expected, workaholism in turn relates positively to two negative outcomes, i.e., work overload and work-family conflict. Specifically, the more self-efficacious an employee is, the more workaholic he or she is and, consequently, the greater the perception of work overload and work-family conflict. Moreover, we found a negative relationship between workaholism and job satisfaction, which again shows the negative quality of this health impairment process. Workaholics work so hard and so compulsively that they have not time to enjoy of their job and, consequently, they do not feel job satisfied.

The positive relationship between work self-efficacy and workaholism is in line with studies that claim that efficacy beliefs not only have positive consequences for employees' well-being, but might also have negative consequences depending on the context and the level of analysis used (Salanova, Lorente, \& Martínez, in press; Vancouver \& Kendall, 2006; Vancouver, Thompson, \& Williams, 2001). For instance, recent studies showed that self-efficacy relates to low performance and low resource allocation (Vancouver \& Kendall, 2006; Vancouver et al., 2002).

But how is work self-efficacy associated with the two dimensions of workaholism? Our findings showed that high levels of work self-efficacy in workaholics imply that they work more hours (excessively), without -apparentrelationship with working in a compulsive way. This result leads us to ask whether the excess of self-efficacy will be 
a possible cause triggering the process of workaholism: is the perception of control directly implicated in spending more time working?

Based on the predictions by $\mathrm{Ng}$ et al. (2007) and Bandura (1997), we could speculate that those individuals who have higher levels of self-efficacy in work activities than in non-work activities are more likely to become workaholics. Because these individuals believe that they are better at dealing with work than with non-work activities, they may devote as much time as they can to work activities and thereby avoid non-work activities at which they are less skilled. Thus, although on the basis of evidence from previous research we cannot assure that the excess of self-efficacy is an important factor that is related to workaholism, it seems that the difference between selfefficacies in different contexts plays an important role.

In a similar way, it is also necessary to consider what psychological mechanism is explaining working compulsively. Compulsive behavior has been studied extensively, especially in the field of clinical psychology, and the general conclusion indicates that its presence depends on personality traits (e.g., McCrae \& Costa, 2003). For instance, there is evidence that low conscientiousness is associated with obsessive-compulsive disorder (Rector, Hood, Richter, \& Bagby, 2002). This link between compulsive behavior and personality leads us to the possible relationship between workaholism and a Type A behavior pattern of personality. Seybold and Salomone (1994) argued that people who exhibit a Type A behavior pattern and also obsessive-compulsive traits are the most likely to become workaholics. Schwartz (1982) also linked compulsive behavior, Type A behavior and workaholism and he stated that people with a Type A behavior pattern and with an obsessive style are commonly workaholics. Thus, future studies would have to take a renewed look at the assessment of personality traits to confirm whether they can be responsible for the compulsive behavior of workaholics.

Furthermore, the results confirm the notion that work overload and work-family conflict are considered negative outcomes for workaholics (e.g., Schaufeli, Taris, \& Bakker, 2008; Snir \& Harpaz, 2004). They also confirm that workaholics, in their attempts to continue working, may go as far as to actively create more work for themselves. For instance, they may make projects more complicated than necessary or refuse to delegate work (Machlowitz, 1980). They are able to increase their work overload day by day and devote less time to social and recreational activities, which are sacrificed in return for spending more time on work (Bonebright, Clay, \& Ankenmann, 2000). This implies that they will often have problems with their families and thus perceive a work-family conflict. Related to this, Bonebright et al. (2000) also found that workaholics had greater work-family conflicts than other non-workaholic employees. Robinson, Flowers, and Carrol (2001) also found that workaholism was associated with more marital problems. Moreover, work overload and work-family conflict can result in other problems such as poor physical health or exhaustion (e.g., Frone, 2003). Therefore, events (both positive and negative) which happen within work and non-work contexts affect one another (e.g., MacEwen \& Barling, 1994), although the interference of work with non-work activities appears to be more common (e.g., Grzywacz \& Marks, 2000).

In sum, we have extended the RED Model (Salanova, Cifre et al., 2011) by including work self-efficacy as an antecedent of workaholism, that is, following the propositions of the model, we can explain how work self-efficacy relates to workaholism, which is also related to work overload and work-family conflict following the health impairment process.

With regard to Hypothesis 2, which proposed that work self-efficacy was positively related to work engagement, which in turn relates positively to job satisfaction and organizational commitment through a motivational process, the results of the SEM showed the expected relationships and thus the second hypothesis was confirmed. On the one hand, work self-efficacy relates positively and significantly to work engagement. According to the RED Model (Salanova, Cifre et al., 2011), people with higher levels of self-efficacy perceive more job resources, fewer job demands and they experience more work engagement than people with low levels of self-efficacy. In fact, the positive relationship between self-efficacy and work engagement has been found in previous studies (e.g., Llorens et al., 2007; Schaufeli \& Salanova, 2007b), which confirms the robustness of our results. Therefore, our analyses confirm that work self-efficacy may produce work engagement following a motivational process in accordance with the RED Model.

On the other hand, work engagement relates positively and significantly to job satisfaction and organizational commitment. Work engaged employees are more satisfied and more committed in their jobs than workers who are not engaged, thus showing the positive effects of promoting work engagement in the workplace. This result is similar to others found in recent research where it has been shown that engaged employees often experience positive emotions (Schaufeli \& Van Rhenen, 2006) and feel job satisfied (e.g., Siu, Spector, Cooper, \& Lu, 2005) . Happy people are more sensitive to opportunities at work, more outgoing and helpful to others, as well as more confident and optimistic (Cropanzano \& Wright, 2001). These aspects impact positively on the organization and must therefore be taken into account by managers in order to implement policies that promote work engagement and job satisfaction.

\section{Theoretical contribution}

Our findings suggest two main contributions. The first one is that we extend the RED Model to explain the role played by work self-efficacy on workaholism and thus, we contribute to the better understanding of the construct, which clearly has a place within the spectrum of occupational 
health, following the health impairment process. Overall, our results show that work self-efficacy is associated with workaholism and work engagement, which are associated with work overload and work-family conflict, and job satisfaction and organizational commitment, respectively. In this way, although the nature of the analyses performed does not allow us to establish causal relationships, the logical reasoning is that, on the one hand, the higher the levels of work self-efficacy are, the more workaholism, work overload and work-family conflict there will be. On the other hand, the higher the levels of work self-efficacy are, the more work engagement there will be, which in turn will enhance job satisfaction, and organizational commitment.

The second contribution of the study refers to the negative condition of workaholism. Our results show a negative relationship between workaholism and job satisfaction, which has also been found in previous studies (e.g., Brady, Vodanovich, \& Rotunda, 2008; Burke, 1999). At the same time this adds weight to other results obtained in this study concerning the effects of work self-efficacy on workaholism, because it proves that workaholism is actually a negative concept with negative consequences (e.g., Porter, 1996, 2001). In addition, this result means that work self-efficacy may also have negative effects on the psychosocial health of employees. Therefore, promoting self-efficacy in the job context does not always have to be a good strategy to improve well-being, particularly if organizations are not aware of the possibly negative role of self-efficacy (for example, also generating workaholism), depending on the circumstances.

In conclusion, this study shows that work self-efficacy can be considered an important variable in understanding and predicting the development of workaholism using the RED Model (Salanova, Cifre et al., 2011).

\section{Implications for future research and for practice}

It is important for future research to examine the effects of work self-efficacy in the workplace in general, and in workaholism in particular. Although in many studies selfefficacy relates positively to positive constructs, our results indicate that it can also be positively related to negative constructs such as workaholism. For this reason, more research is necessary to test if work self-efficacy may be a possible cause triggering the process of workaholism. Moreover, it is very important for organizations to complete self-efficacy training with information about its possible negative consequences and also with instruction in other relevant aspects such as how to maintain a healthy balance between work and non-work environments. Only with this extra information, organizations will be able to promote selfefficacy with less risk to experience negative consequences. Hence, this result contributes to the study of workaholism by showing how self-efficacy also has a dark side that can become the 'on button' in the workaholism process.
Moreover, despite the remarkable importance of our findings in relation to work self-efficacy effects on workaholism, future research might find other variables that have an influence on workaholic behavior, such as the Type A behavior pattern, for instance. It can be speculated that underlying psychological mechanisms, such as motivational systems, would exert an influence on workaholism. More particularly, and considering workaholism and work engagement, workaholics are likely to be motivated by socalled performance goals, whereas engaged workers are motivated by mastery goals (Elliot, 2005; Elliot \& Murayama, 2008). The former are competitive, other-referenced, and extrinsic, whereas the latter are directed at self-enhancement, self-referenced, and intrinsic. Similarly, it can be argued that the behavior of workaholics is primarily regulated by a prevention focus, whereas the behavior of engaged employees is regulated by a promotion focus. Based on regulatory focus theory (Higgins, 2005; Scholer \& Higgins, 2008), it can be speculated that workaholics work excessively and compulsively because they want to avoid feeling bad (i.e., guilty or worthless) when they are not working (avoidance motivation). However, engaged workers work because it fosters possibilities for learning and development (approach motivation).

\section{Weaknesses and strengths of the study}

One weakness of this study is that the results were obtained by self-report measures, and consequently may be contaminated by the common method variance and by the wish to answer consistently (Conway, 2002). In order to control for this, we checked the potential impact of common method variance in our data (see Podsakoff et al., 2003). Although we cannot completely rule out the possibility that the common method variance bias is playing a role, our check for it proved negative.

Another weakness of this study is that we assumed a unidirectional view of the relations among the variables measured. Structural models such as the RED Model focus on specific aspects of the complex psychosocial work environment in order to explain how individuals perceive and react to their job and to postulate that the relations between personal resources and workaholism or work engagement, for instance, are unidirectional. Therefore, it would be useful to develop longitudinal designs instead of cross-sectional designs in order to uncover reciprocal causal relationships. This type of studies would also be useful to examine the spirals proposed by the RED Model (see Salanova, Cifre et al., 2011).

\section{Final Remark}

To sum up, the current study shows the twofold role of work self-efficacy. It is related not only to work engagement and its positive outcomes (e.g., job satisfaction and 
organizational commitment), but also to workaholism and its negative outcomes (e.g., work overload and work-family conflict) following the motivational and the health impairment process. Thus, this study contributes to our understanding about the potential dark and bright sides of self-efficacy: workaholism and work engagement.

\section{References}

Bakker, A. B., Demerouti, E., \& Euwema, M. C. (2005). Job resources buffer the impact of job demands on burnout. Journal of Occupational Health Psychology, 10, 170-180. http://dx.doi.org/10.1037/1076-8998.10.2.170

Bakker, A. B., Demerouti, E., \& Schaufeli, W. B. (2003). Dual processes at work in a call centre: An application of the job demands-resources model. European Journal of Work and Organizational Psychology, 12, 393-417. http://dx.doi.org/10. 1080/13594320344000165

Bandura, A. (1997). Self-efficacy: the exercise of control. New York, NY: Freeman.

Bandura, A. (2001). Guía para la construcción de escalas de autoeficacia. [Guide for constructing self-efficacy scales]. Palo Alto, CA: Stanford University. Retrieved from http://www. des.emory.edu/mfp/effguideSpanish.html.

Beehr, T. A., Walsh, J. T., \& Taber, T. D. (1976). Relationship of stress to individually and organizationally valued states: Higher order needs as a moderator. Journal of Applied Psychology, 61, 41-47. http://dx.doi.org/10.1037/0021-9010.61.1.41

Bonebright, C. A., Clay, D. L., \& Ankenmann, R. D. (2000). The relationship of workaholism with work-life conflict, life satisfaction, and purpose in life. Journal of Counseling Psychology, 47, 469-477. http://dx.doi.org/10.1037/0022-0167. 47.4.469

Brady, B. R., Vodanovich, S. J., \& Rotunda, R. (2008). The impact of workaholism on work-family conflict, job satisfaction, and perception of leisure activities. The Psychologist-Manager Journal, 11, 241-263. http://dx.doi.org/10.1080/1088715080 2371781

Browne, M. W., \& Cudeck, R. (1993). Alternative ways of assessing model fit. In K. A. Bollen \& S. J. Long (Eds.), Testing structural equation models (pp. 136-162). Beverly Hills, C.A: Sage.

Burke, R. J. (1999). Workaholism in organizations. Measurement validation and replication. International Journal of Stress Management, 6, 45-55. http://dx.doi.org/10.1023/A:10219 10303807

Burke, R. J., Matthiesen, S. B., \& Pallesen, S. (2006). Personality correlates of workaholism. Personality and Individual differences, 40, 1223-1233. http://dx.doi.org/10.1016/j.paid. 2005.10.017

Byrne, B. M. (2001). Structural equation modeling with AMOS: Basic concepts, applications and programming. Mahway, NJ - London, England: Lawrence Erlbaum Associates, Publishers.

Caplan, R. D., Cobb, S., French, J. R. P., Harrison, R. V., \& Pinneau, S. R. (1975). Job demands and worker health: Main effects and occupational differences. Washington, DC: US Department of Health, Education, and Welfare.

Conway, J. M. (2002). Method variance and method bias in industrial and organizational psychology. In S. G. Rogelberg (Ed.), Handbook of Research Methods in Organizational and Industrial Psychology (pp. 344-365). Malden, NJ: Blackwell Publishers.

Cropanzano, R., \& Wright, T. A. (2001). When a 'happy' worker is really a 'productive' worker: A review and further refinement of the happy-productive worker thesis. Consulting Psychology Journal: Practice and Research, 53, 182-199. http://dx.doi. org/10.1037/1061-4087.53.3.182

Del Líbano, M., Llorens, S., Salanova, M., \& Schaufeli, W. B. (2010). Validity of a brief workaholism scale. Psicothema, 22, 143-150.

Demerouti, E., Bakker, A. B., Nachreiner, F., \& Schaufeli, W. B. (2001). The job demands-resources model of burnout. Journal of Applied Psychology, 86, 499-512. http://dx.doi.org/10.1037/ 0021-9010.86.3.499

Eden, D. (2001). Vacations and other respites: Studying stress on and off the job. In C. L. Cooper \& I. T. Robertson (Eds.), International review of industrial and organizational psychology (Vol. 16, pp. 121-146). Chichester, UK: Wiley.

Ellias, S., \& MacDonald, S. (2007). Using past performance, proxy efficacy, and academic self-efficacy to predict college performance. Journal of Applied Social Psychology, 37, 2518-2531. http://dx.doi.org/10.1111/j.1559-1816.2007.00268.x

Elliot, A. J. (2005). A conceptual history of the achievement goal construct. In A. J. Elliot \& C. S. Dweck (Eds), Handbook of competence and motivation (pp. 52-72). New York, NY: Guilford.

Elliot, A. J., \& Murayama, K. (2008). On the measurement of achievement goals: Critique, illustration, and application. Journal of Educational Psychology, 100, 613-628. http://dx. doi.org/10.1037/0022-0663.100.3.613

Frone, M. R. (2003). Work-family balance. In J. C. Quick \& L. E. Tetrick (Eds.), Handbook of occupational health psychology (pp. 143-162). Washington, DC: American Psychological Association.

Grau, R., Salanova, M., \& Peiró, J. M. (2000). Efectos moduladores de la autoeficacia en el estrés laboral [Moderators effects of self-efficacy in job stress]. Apuntes de Psicología, 18, 57-75.

Grzywacz, J. G., \& Marks, N. F. (2000). Family, work, workfamily spillover and problem drinking during midlife. Journal of Marriage \& the Family, 62, 336-348. http://dx.doi.org/ 10.1111/j.1741-3737.2000.00336.x

Hackman, J. R., \& Oldham, G. R. (1980). Work redesign. Reading, MA: Addison Wesley.

Higgins, T. (2005). Value from regulatory fit. Current Directions in Psychological Science, 14, 209-213. http://dx.doi.org/10. 1556/JCEP.2.2004.1-2.1

Hobfoll, S. E., Johnson, R. J., Ennis, N., \& Jackson, A. P. (2003). Resource loss, resource gain, and emotional outcomes among inner city women. Journal of Personality and Social Psychology, 84, 632-643. http://dx.doi.org/10.1037/0022-3514.84.3.632 
Hoyle, R. H. (1995). Structural Equation Modeling. Thousand Oaks, CA: SAGE Publications.

Iverson, R. D., \& Maguire, C. (2000). The relationship between job and life satisfaction: Evidence from a remote mining community. Human Relations, 53, 807-839. http://dx.doi.org/ 10.1177/0018726700536003

Jöreskog, K. G., \& Sörbom, D. (1986). PRELIS: A program for multivariate data screening and data summarization. Mooresville, IL: Scientific Software.

Judge, T. A., Jackson, C. L., Shaw, J. C., Scott, B. A., \& Rich, B. L. (2007). Self-efficacy and work-related performance: The integral role of individual differences. Journal of Applied Psychology, 92, 107-127. http://dx.doi.org/10.1037/0021-9010.92.1.107

Judge, T.A., \& Bono, J. E. (2001). Relationship of core selfevaluation traits- self-esteem, generalized self-efficacy, locus of control, and emotional stability - with job satisfaction and job performance: A meta-analysis. Journal of Applied Psychology, 86, 80-92. http://dx.doi.org/10.1037/0021-9010.86.1.80

Kanai, A. (2009). Karoshi (work to death) in Japan. Journal of Business Ethics, 84, 209-216. http://dx.doi.org/10.1007/s10551008-9701-8

Kanai, A., \& Wakabayashi, M. (2001). Workaholism among Japanese blue-collar employees. International Journal of Stress Management, 8, 129-145. http://dx.doi.org/10.4263/jorthoptic. 29.291

Kanai, A., Wakabayashi, M., \& Fling, S. (1996). Workaholism among employees in Japanese corporations: An examination based on the Japanese version of the Workaholism Scales. Japanese Psychological Research, 38, 192-203. http://dx.doi. org/10.1111/j.1468-5884.1996.tb00024.x

Karasek, R. A. (1979). Job demands, job decision latitude and mental strain. Implications for job redesign. Administrative Science Quarterly, 24, 285-308. http://dx.doi.org/10.2307/ 2392498

Killinger, B. (1992). Workaholics, the respectable addicts. East Roseville, Australia: Simon and Schuster.

Kunin, T. (1955). The construction of a new type of attitude measure. Personnel Psychology, 8, 65-67. http://dx.doi.org/ 10.1111/j.1744-6570.1955.tb01189.x

Latham, G. (2005). Work motivation theory and research at the dawn of the twenty-first century. Annual review of Psychology, 56, 485-516. http://dx.doi.org/10.1146/annurev.psych.55.0909 02.142105

Llorens, S., Bakker, A. B., Schaufeli, W. B., \& Salanova, M. (2006). Testing the robustness of the "Job Demands-Resources" model. International Journal of Stress Management, 13, 378391. http://dx.doi.org/10.1037/1072-5245.13.3.378

Llorens, S., Schaufeli, W. B., Bakker, A., \& Salanova, M. (2007). Does a positive gain spiral of resources, efficacy beliefs and engagement exist? Computers in Human Behavior, 23, 825841. http://dx.doi.org/10.1016/j.chb.2004.11.012

MacEwen, K. E., \& Barling, J. (1994). Daily consequences of work interference with family and family interference with work. Work and Stress, 13, 59-73. http://dx.doi.org/10.1080/ 02678379408259996
Macey, W. H., \& Schneider, B. (2008). The meaning of employee engagement. Society for Industrial and Organizational Psychology, 1, 3-30. http://dx.doi.org/10.1111/j.1754-9434.2007.0002.x

Machlowitz, M. (1980). Workaholics: Living with them, working with them. Reading, MA: Addison-Wesley.

Marsh, H. W., Balla, J. R., \& Hau, K. T. (1996). An evaluation of incremental fit indexes: A clarification of mathematical and empirical properties. In G. A. Marcoulides \& R. E. Schumacker (Eds.), Advanced structural equation modeling techniques (pp.315-353). Mahwah, NJ: Lawrence Erlbaum.

McCrae, R. R., \& Costa, P. T. (2003). Personality in adulthood. New York, NY: The Guilford Press.

Ng, T. W. H., Sorensen, K. L., \& Feldman, D. C. (2007). Dimensions, antecedents, and consequences of workaholism: A conceptual integration and extension. Journal of Organizational Behavior, 28, 111-136. http://dx.doi.org/10. 1002/job.424

Nunnally, J. C., \& Bernstein, I. H. (1994). Psychometric theory ( $3^{\text {rd }}$ Ed.). New York, NY: McGraw-Hill.

Oates, W. E. (1971). Confessions of a Workaholic: The facts about work addiction. New York, NY: World.

Pajares, F, \& Miller, M. D. (1995). Mathematics self-efficacy and mathematics performances: The need for specificity of assessments. Journal of Counseling Psychology, 42, 190-198. http://dx.doi.org/10.1037/0022-0167.42.2.190

Parker, S. K. (2000). From passive to proactive motivation: The importance of flexible role orientations and role breadth selfefficacy. Applied Psychology: An International Review, 49, 447-469. http://dx.doi.org/10.1111/1464-0597.00025

Podsakoff, P. M., MacKenzie, S. B., Lee, J. Y., \& Podsakoff, N. P. (2003). Common method biases in behavioral research: A critical review of the literature and recommended remedies. Journal of Applied Psychology, 88, 879-903. http://dx.doi.org/ 10.1037/0021-9010.88.5.879

Porter, G. (1996). Organizational impact of workaholism. Suggestions for researching the negative outcomes of excessive work. Journal of Occupational Health Psychology, 1, 70-84. http://dx.doi.org/10.1037/1076-8998.1.1.70

Porter, G. (2001). Workaholic tendencies and the high potential for stress among co-workers. International Journal of Stress Management, 8, 147-164. http://dx.doi.org/10.1023/A:100958 1330960

Rector, N. A., Hood, K., Richter, M. A., \& Bagby, R. M. (2002). Obsessive-compulsive disorder and the five-factor model of personality: Distinction and overlap with major depressive disorder. Behaviour Research and Therapy, 40, 1205-1219. http://dx.doi.org/10.1016/S0005-7967(02)00024-4

Robinson, B. E., Flowers, C., \& Carroll, J. J. (2001).Work stress and marriage: A theoretical model examining the relationships between workaholism and marital cohesion. International Journal of Stress Management, 8, 165-175. http:/dx.doi.org/ 10.1023/A:1009533415030

Salanova, M., \& Schaufeli, W. (2009). El engagement en el trabajo. Cuando el trabajo se convierte en pasión [Work engagement: When job becomes passion]. Madrid, Spain: Alianza. 
Salanova, M., Cifre, E., Martínez, I., \& Llorens, S. (2007). Caso a caso en la prevención de riesgos psicosociales. Metodología WONT para una organización saludable. [Case to case in the prevention of psychosocial risks. WoNT Methodology for a healthy organization]. Bilbao, Spain: Lettera Publicaciones.

Salanova, M., Cifre, E., Martínez, I. M., Llorens, S., \& Lorente, L. (2011). Psychosocial risks and positive factors among construction workers. In S. Clarke, C. Cooper, \& R. Burke (Eds.), Occupational health and safety: Psychological and behavioral challenges (pp. 295-320). Farnham, England: Gower.

Salanova, M., Grau, R., Llorens, S., \& Schaufeli, W. B. (2001). Exposición a las tecnologías de la información, burnout y engagement: El rol modulador de la autoeficacia [Exposure to information technologies, burnout and engagement: The moderator role of self-efficacy]. Revista de Psicología Social Aplicada, 11, 69-90.

Salanova, M., Llorens, S., \& Schaufeli, W. B. (2011). Yes, I can, I feel cood and I just do it! On gain cycles and spirals of efficacy beliefs, affect, and engagement. Applied Psychology: An International Review, 60, 255-285. http://dx.doi.org/10. 1111/j.1464-0597.2010.00435.x

Salanova, M., Llorens, S., Cifre, E., Martínez, I., \& Schaufeli, W. B. (2003). Perceived collective efficacy, subjective well-being and task performance among electronic work groups: An experimental study. Small Groups Research, 34, 43-73. http://dx.doi.org/10.1177/1046496402239577

Salanova, M., Lorente, L., \& Martínez, I. (in press). The dark and bright sides of self-efficacy in predicting learning, innovative and risky performance. The Spanish Journal of Psychology.

Salanova, M., Lorente, L., \& Vera, M. (2009). Recursos personales: Las creencias de eficacia [Personal resources: Efficacy beliefs]. In M. Salanova (Ed.), Psicología de la salud ocupacional positiva [Positive and Occupational Health Psychology] (pp. 149-176). Madrid, Spain: Síntesis.

Salanova, M., Lorente, L., Chambel, M. J., \& Martínez, I. (2011). Linking transformational leadership to nurses extra-role performance: The mediating role of self-efficacy and work engagement. Journal of Advanced Nursing, 67, 2256-2266. http://dx.doi.org/10.1111/j.1365-2648.2011.05652.x

Salanova, M., Peiró, J. M., \& Schaufeli, W. B. (2002). Self-efficacy specificity and burnout among information technology workers: An extension of the job demands-control model. European Journal of Work and Organizational Psychology, 11, 1-25. http://dx.doi.org/10.1080/13594320143000735

Salanova, M., Schaufeli, W. B., Llorens, S., Peiró, J. M., \& Grau, R. (2000). Desde el 'burnout' al 'engagement': ¿Una nueva perspectiva? [From burnout to engagement: A new perspective?] Revista de Psicología del Trabajo y las Organizaciones, 16, 117-134.

Salanova, M., Schaufeli, W. B., Xanthopoulou, D., \& Bakker, A. (2010). The gain spiral of resources and work engagement: Sustaining a positive worklife. In A. Bakker, \& M. Leiter (Eds.), Work engagement: A Handbook of Essential theory and research (pp. 118-131). New York, NY: Psychology Press.
Schaufeli, W. B., \& Bakker, A. B. (2004). Job demands, job resources and their relationship with burnout and engagement: A multi-sample study. Journal of Organizational Behavior, 25, 293-315. http://dx.doi.org/10.1002/job.248

Schaufeli, W. B., Bakker, A. B., \& Salanova, M. (2006). The measurement of work engagement with short questionnaire. Educational and Psychological Measurement, 66, 701-716. http://dx.doi.org/10.1177/0013164405282471

Schaufeli, W. B., \& Salanova, M. (2007a). Efficacy or inefficacy, that's the question: Burnout and engagement, and their relationships with efficacy beliefs. Anxiety, Stress \& Coping, 20, 177-196. http://dx.doi.org/10.1080/10615800701217878

Schaufeli, W. B., \& Salanova, M. (2007b). Work engagement: An emerging psychological concept and its implications for organizations. In. S.W. Gilliland, D. D. Steiner, \& D. P. Skarlicki (Eds.), Managing social and ethical issues in organizations (pp.135-177). Greenwich, CT: IAP.

Schaufeli, W. B., Salanova, M., González-Romá. V., \& Bakker, A. B. (2002). The measurement of engagement and burnout: A confirmatory factor analytic approach. Journal of Happiness Studies, 3, 71-92. http://dx.doi.org/10.1023/A:1015630930326

Schaufeli, W. B., \& Van Rhenen, W. (2006). Over de rol van positieve en negatieve emoties bij het welbevinden van managers: Een studie met de Job-related Affective Well-being Scale (JAWS). [About the role of positive and negative emotions in managers' well-being: A study using the Job-related Affective Well-being Scale (JAWS)]. Gedrag \& Organisatie, 19, 323-244.

Schaufeli, W. B., Shimazu, A., \& Taris, T. W. (2009). Being driven to work excessively hard: The evaluation of a two-factor measure of workaholism in the Netherlands and Japan. CrossCultural Research, 43, 320-348. http://dx.doi.org/10.1177/ 1069397109337239

Schaufeli, W. B., Taris, T. W., \& Bakker, A. (2006). Dr. Jekyll and Mr. Hide: On the differences between work engagement and workaholism. In R. Burke (Ed), Research companion to working time and work addiction (pp. 193-217). Northampton, MA: Edward Elgar.

Schaufeli, W. B., Taris, T. W., \& Van Rhenen, W. (2008). Workaholism, burnout and engagement: Three of a kind or three different kinds of employee well-being. Applied Psychology: An International Review, 57, 173-203. http://dx. doi.org/10.1111/j.1464-0597.2007.00285.x

Schaufeli, W. B., Taris, T., \& Bakker, A. B. (2008). It takes two to tango. Workaholism is working excessively and working compulsively. In R. J. Burke \& C. L. Cooper (Eds.), The long work hours culture. Causes, consequences and choices (pp. 203-226). Bingley. England: Emerald.

Scholer, A. A., \& Higgins, E. T. (2008). Distinguishing levels of approach and avoidance: An analysis using regulatory focus theory. In A. J. Elliot (Ed.), Handbook of Approach and Avoidance Motivation (pp. 489-504). New York, NY: Psychology Press.

Schwartz, H. S. (1982). Job involvement as obsession-compulsion. Academy of Management Review, 7, 429-432. http://dx.doi.org/ $10.2307 / 257335$ 
Seybold, K. C., \& Salomone, P. R. (1994). Understanding workaholism: A review of causes and counseling approaches. Journal of Counseling and Development, 73, 4-9. http://dx. doi.org/10.1002/j.1556-6676.1994.tb01702.x

Siu, O., Spector, P., Cooper, C., \& Lu, Ch. (2005). Work stress, self-efficacy, Chinese work values, and work well-being in Hong Kong and Beijing. International Journal of Stress Management, 3, 274-288. http://dx.doi.org/10.1037/10725245.12.3.274

Snir, R., \& Harpaz, I. (2004). Attitudinal and demographic antecedents of workaholism. Journal of Organizational Change Management, 17, 520-536. http://dx.doi.org/10.1108/0953481 0410554524

Sonnentag, S., \& Kruel, U. (2006). Psychological detachment from work during off-job time: The role of job stressors, job involvement, and recovery-related self-efficacy. European Journal of Work and Organizational Psychology, 15, 197217. http://dx.doi.org/10.1080/13594320500513939

Spence, J. T., \& Robbins, A. S. (1992). Workaholism: Definition, measurement, and preliminary results. Journal of Personality Assessment, 58, 160-178. http://dx.doi.org/10.1207/s15327752 jpa5801_15

Stajkovic, A. D., Lee, D., \& Nyberg, A. J. (2009). Collective efficacy, group potency, and group performance: Meta-analyses of their relationships, and test of mediation model. Journal of Applied Psychology, 94, 814-828. http://dx.doi.org/10. 1037/a0015659
Vancouver, J. B., \& Kendall, L. N. (2006). When self-efficacy negatively relates to motivation and performance in a learning context. Journal of Applied Psychology, 91, 1146-1153. http://dx.doi.org/10.1037/0021-9010.91.5.1146

Vancouver, J. B., Thompson, C. M., Tischner, E. C., \& Putka, D. J. (2002). Two studies examining the negative effects of selfefficacy on performance. Journal of Applied Psychology, 87, 506-516. http://dx.doi.org/10.1037/0021-9010.87.3.506

Vancouyer, J. B., Thompson, C. M., \& Williams, A. A. (2001). The changing signs in the relationships among self-efficacy, personal goals, and performance. Journal of Applied Psychology, 86, 605-620. http://dx.doi.org/10.1037/00219010.86.4.605

Xanthopoulou, D., Bakker, A. B., Demerouti, E., \& Schaufeli, W. B. (2007). The role of personal resources in the job demands-resources model. International Journal of Stress Management, 14, 121-141. http://dx.doi.org/10.1037/10725245.14.2.121

Xanthopoulou, D., Bakker, A. B., Heuven, E., Demerouti, E., \& Schaufeli, W. B. (2008). Working in the sky: A dairy study among flight attendants. Journal of Occupational Health Psychology, 13, 345-356. http://dx.doi.org/10.1037/10768998.13.4.345

Received November 27, 2010

Revision received May 6, 2011 Accepted July 14, 2011 